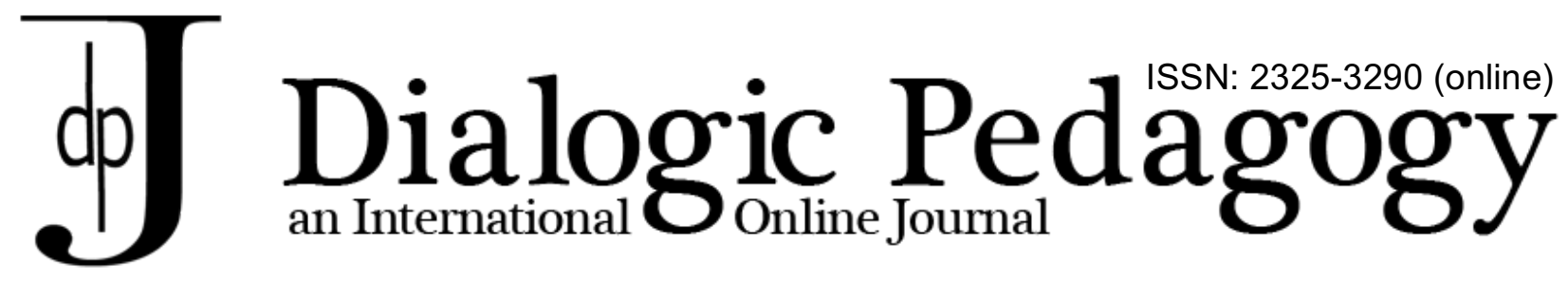

\title{
The Use-Value of Real-World Projects: Children and Local Experts Connecting Through School Work
}

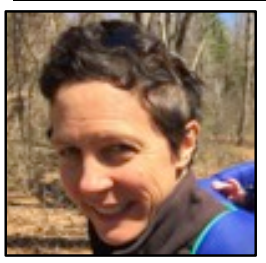

Alison Rheingold

Christa McAuliffe Charter School

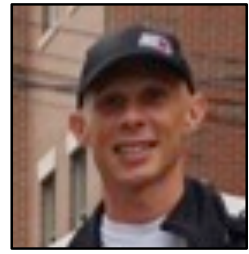

Jayson Seaman

University of New Hampshire

\begin{abstract}
In this paper we discuss how the products of student work during long-term, interdisciplinary curricular units at King Middle School, a grades 6-8 public school in Portland, Maine, through their aesthetic qualities, transformed people's understanding of what children were capable of. We argue that, to effectively understand student work of this type, 'cognitive' and 'practical' criteria for evaluation - i.e., as a supposed indicator of what students need to know and be able to do - fail to convey the actual, substantive value of the work, rendering it relatively static and meaningless like much conventional schoolwork. Instead, we argue that aesthetic criteria can help to adequately understand and assess community-based, project work. Moreover, focusing only on student learning throughout the production process occludes the importance of collaboration, communication, and dialogue with an audience: in this case, community experts whose goals and interests must be accommodated as students do their work. The aim of the article is twofold: 1) to present a coherent picture of student project work that adequately captures its complexity both in the process of its production, and in its use-value upon completion; and 2) to argue for the importance of aesthetic criteria in planning and assessing student projects.
\end{abstract}

Dr. Alison Rheingold is the Director of Professional Learning at the Christa McAuliffe Charter School in Framingham, Massachusetts. Her primary role is to develop teachers' passion for designing and implementing community-based, interdisciplinary curriculum for middle school children.

Jayson Seaman is Associate Professor of Kinesiology and Affiliate Associate Professor of Education at the University of New Hampshire. His research interests include the historical foundations of experiential education, youth development, learning in informal settings, and adolescent identity formation. He is the co-author (with John Quay) of John Dewey and Education Outdoors (Sense, 2013).

$\cos 0380$ 


\section{Introduction}

The function of art has always been to break through the crust of conventionalized and routine consciousness (John Dewey, 1927/1954, p. 183)

Something almost indescribable happens when adults see beautiful work created by children, or when an audience watches a child's top-notch performance; they become overtly emotional, perhaps wondering, "How can a child of this age have produced something that good?" Or they might observe: "I am impressed that the child cared enough to work that hard on the project." When children's academic work embodies certain qualities, it can be much more than a demonstration of content knowledge and skills - it can transform students and audiences, functioning as art in the sense John Dewey describes.

This paper discusses how the products of student work during long-term curricular units at one public middle school demonstrated this kind of aesthetic quality. We argue that, to effectively understand student work of this type, 'cognitive' and 'practical' criteria for evaluation- i.e., as a supposed indicator of what students need to know and be able to do - fail to convey the actual, substantive value of the work, rendering it relatively static and meaningless like much conventional schoolwork. We argue that aesthetic criteria helps to adequately understand and assess project work, particularly when it communicates meaning and value to people outside of the school. Moreover, focusing only on student learning during project work obscures the importance of collaboration, communication, and dialogue with an audience: in this case, local experts whose goals and interests must be accommodated throughout the production process. We therefore also argue for seeing student labor on real world projects as "boundary work" (Star \& Griesemer, 1989) - crucial to understanding the ultimate value of what they produce.

The purpose of the article is twofold: 1) to present a coherent picture of student project work that captures its complexity both in the process of its production, and in its use-value upon completion; and 2) to argue for the importance of aesthetic criteria in planning and assessing student projects. Our broader aim is to show the provocative nature of aesthetic criteria for assessing the quality of educational outcomes.

\section{Overview of the Study}

For over 20 years, children at King Middle School, a school serving grades 6-8 in Portland, Maine ("King") have created high-quality products and performances of academic work through a model of school reform that focuses on heterogeneous grouping, extended, interdisciplinary, community-based research projects, and sharing student work with audiences. Because of the type of academic inquiry, the quality of student work, and the recognition this school has received over time, students' products and performances have been seen and used by people throughout the United States and elsewhere in the world. For example, King was profiled on edutopia.com as a 'school that works' and was featured in 2010 on Korean public television program as a 'school of the future.'

Much of students' academic work at King, especially the kind of long-term, interdisciplinary projects that provided the context of this study, is done alongside local partners - people from the Portland area who actively participate in the planning and execution of academic projects. Students engage in research that often stems from expressed needs of these outside experts. Examples include scientists, journalists, architects, graphic designers, artists, and city council members. Sometimes these experts are also parents of students at King. Through their joint work, students, teachers, and local experts negotiate their understanding of the work, each other, and the broader region. (For specific examples of projects, see Dobbertin (2010)). 
What students produce at this school is radically different from ordinary schoolwork. In many schools, students' work (literally) falls into what Sidorkin (2001) calls the "wastebasket economy." Sidorkin urges a focus on the use value of student products. He argues that the value of student work - what they make through their labor - at any school depends on many factors including what students produce, why it was created, and who 'uses' or 'consumes' it. Based on these criteria, unlike consumer commodities, most student work has no use value at all. Imagine a worksheet or test: children labor to produce them but cannot use them, parents cannot use them, and even teachers cannot use them except as a rationale for doing and keeping their jobs (they require grading). Therefore the 'use value' of most student work is nil: at best, it might end up on a parent's refrigerator as a nostalgic artifact, but most ends up in the recycle bin. In school, "learning is a byproduct of making useless things," Sidorkin writes (2001, p. 94). The psychological consequences of endlessly making useless things are predictably severe, resulting in de-motivation and alienation from one's creative potential as well as from the social communities that confer value on one's work (Lave, 1990; Lave \& McDermott, 2002).

Advocates of project-based learning have compellingly argued that projects disrupt the typical disutility of schoolwork and therefore possess much stronger motivational potential (e.g., Blumenfeld et al., 1991). Two elements are central to this line of argument: projects' collaborative nature (Poortvliet \& Darnon, 2010) and the use value of what students actually produce (Wardekker, Boersma, Ten Dame, \& Volman, 2011). These 'affordances' give project work a kind of dual valence: their work is born from a desire to associate with peers as well as a sense that what one produces will mean something to someone other than the teacher. And, awareness that one's work will receive scrutiny by an outside audience can add additional motivational force (Magnifico, 2010).

Rarely considered in these arguments, however, is what student work does for its recipients outside the school: the group, ostensibly, who ultimately will confer value. Some authors have focused on the potential benefit of service learning, asking, "How did community partners perceive the program?" (Baker \& Murray, 2011, p. 125). Likewise, Sanders (2006) lays out a range of successful school partnerships, which on the "extensive" end include "long term, bi or multidirectional, high level of interaction, extensive planning and coordination" (p. 8)

But what is the actual value of student work - the things children produce? Moreover, how should this value be considered? We believe this is a crucial question that, as our analysis will show, affects how project work might be more fully understood, as well as having implications for the dialogic potential of this work in educational settings. At King, for example, a significant amount of students' work possesses the above affordances. It is very different from work that more typically earns only a teacher's, and perhaps a parent's, scrutiny. Teachers in all content areas at King purposefully aim students toward work modeled after a professional's, and student products are indeed of such a high degree of quality to be worthy of genuine praise (U.S. Secretary of Education Arne Duncan lauded compliments on it in a 2010 visit). But, there is quality work and then there is quality work; at the middle school level, it is quite rare for students to produce work that approaches that of professionals - and, importantly, no one really expects this. Nonetheless, the animating discourse at King is for students to approximate the work of professionals, for students to experience application of their work outside of the school, and to shift learning outcomes to align with what people do in the 'real' world, rather than just developing abstract skills and knowledge as they produce things bound for the wastebasket. And, student work is more than token, because the response from students and community members alike is usually overwhelmingly positive (judging by its continuation now over decades).

If students repeatedly create products and performances that relate to tangible outcomes outside of the school, then it follows that there is ongoing value to the students and to communities of practice 
outside the school. But what is the nature of this 'value?' Is what local individuals and groups value the same as what school members intend? Upon inspection, it becomes apparent that the value of student work is likely discontinuous across involved parties - students might perceive use value in products of their labor that local professionals would never use. The concepts of 'exchange value' and 'use value' as in critical theories (e.g., Apple, 1990; Roth, 2011; Wardekker et al., 2011) do not alone explain how projects sustain meaningful collaboration and dialogue across the schooling and local/professional domains. In this study, we asked: what can be learned from investigating value in this kind of project work, and what might the findings mean to questions of curriculum design and assessment, and, more deeply, the nature of student work in school? The research described in the remainder of the paper sought to understand the 'use value' of student work at King Middle School by soliciting the perspectives of local experts involved in it.

\section{A starting example - The field guide}

Here we provide an exemplar to illustrate qualities of student artifacts produced alongside local experts. Over the years, students at King have created numerous field guides to surrounding natural areas. Field guides, as a type of academic product, have two inherent qualities that are critical to our research: field guides can be both useful and beautiful. The process of creating a field guide involves extensive fieldwork with local partners, research into the items to be included in the guide, scientific writing, and artwork (in these cases, drawing of the species displayed in the guide - originally done in color). See Figure 1 on next page for an example of work from a field guide that students created in 1995, examining plants and animals living in the intertidal zone of local Casco Bay.

No field guide of this sort existed. Students, with local experts and teachers, worked tirelessly on each entry, starting by examining plants or animals in the field (in this case actually in the water, using snorkels and wetsuits), and ending with extensive drafts and critiques of their writing and scientific drawings. The book, when complete, was bound, published, and sold around the area. More than just being a useful book, the artifact (the field guide) and project (the process through which students learned about the species in the intertidal zone) launched field-guide projects both at King and at other schools around the country. This project was also used during a keynote speech as a model at Expeditionary Learning's 2010 Annual Conference ${ }^{1}$. As discussed throughout this paper, the beauty and usefulness of students' work (even when 'useful' is defined differently for different players) propels the artifacts and students into future, meaning-making roles.

\section{Conceptual Framework}

\section{Boundary Objects and Boundary Crossing}

Our research was informed by a social practice perspective on learning, specifically cultural historical activity theory (CHAT) and Deweyan pragmatism, two frameworks that have been combined elsewhere (Miettinen, 2001; Miettinen, 2006). In this section, we discuss a main principle in CHAT artifact mediation - and introduce the concepts of boundary objects and boundary crossings as a way to examine both the process and the products of student work in real-world curriculum projects. These concepts alone, however, do not explain why student projects - few of which, we surmise, actually

\footnotetext{
${ }^{1}$ As of 2015, Expeditionary Learning is known as EL Education.
} 


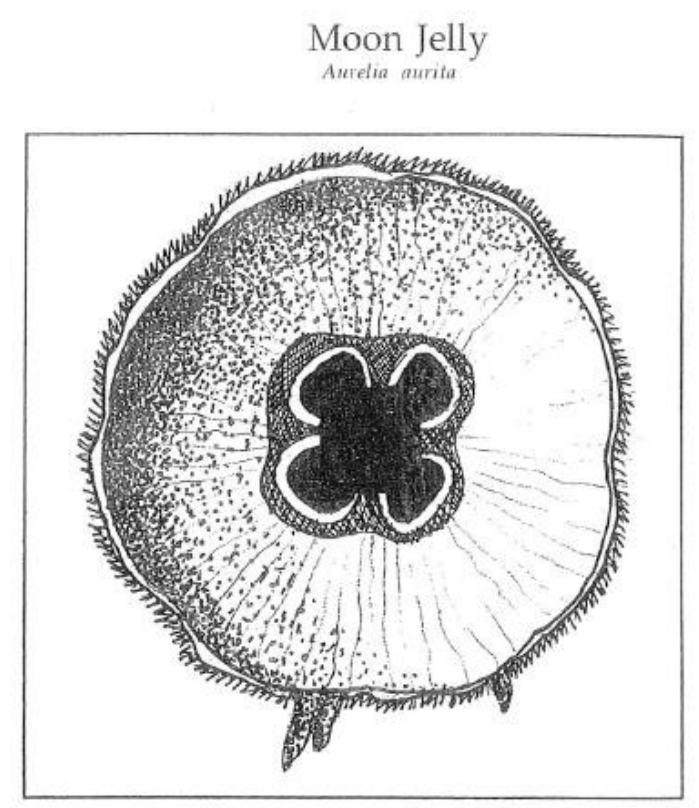

General Description: Moon Jellies have four, white, U-shaped bodies that are visible through a milk-white jelly bell. Its color ranges from tan to orange-pink.

Habitat: Its habitat is in the intertidal zones in summer. They can be stranded in low tide pools by strong winds and ebb tides. Moon jellies may move and swim in mid to top water where humans usually are. They probably live close to the top water

45 because that's where their foods live and because at the bottom of the ocean, there are corals reefs and other hard animals and plants. A jellyfish needs softness and space.

Geographic Range: Moon Jellies appear in spring and summer in Cape Cod bays. By July they can appear in Maine. They also live in tropical waters around the world.

How it Protects itself: Its protection is its stinging tentacles which give a rash if handled. The predator who eats it may die. The sting is deadly, more deadly than a snake bite to some smaller organisms.

Uses: Unknown

Observations: When Moon Jellies die they evaporate into water because they are $96 \%$ water.

Reproduction: The mature jellies produce eggs and sperm cells by late July or August. In autumn, eggs hatch into larvae that attach to lower level rocks in crevices and tides pool on sheltered shores. Miniature moon jellies released early in spring reach sexual maturity in six months to two years.

Food Chain: They eat plankton and small crustaceans. Animals that eat moon jellies include bigger fish

Life Span: Their deaths are caused by October storms. The moon jellies can travel 50 miles or more before it dies.

Charanan Tok

Figure 1: Shown here are two pages of a field guide called "Into the Zone: Where Land Meets the Water - A Field Guide to the Marine Life in the Tidal Zone of Northern New England."

provide the kind of use-value expected from professional-quality products - are often immensely satisfying for students, school personnel, and local stakeholders, defying understanding in terms of narrow utility.

Artifact mediation and boundary objects.

In a CHAT framework, knowledge and knowing are distributed among people and objects and across time, rather than being seen as static, individual properties. 'Things' are mediators; people learn through the creation and use of tools - whether material or conceptual. As CHAT perspectives have evolved (i.e., third generation CHAT) the unit of analysis is thought of as the interaction between and across activity systems, such as schools and professional domains of paid, scientific, or civic work, the contradictions that are negotiated in this 'zone' are of interest methodologically and empirically as they form the basis for development (Engeström, 1987; Roth, 2007).

In an article that describes how school-based learning can approach the work of professional scientists, Ford and Forman (2006) write: "The material aspect is intertwined with the social aspect, because it characterizes what the public discussions are about and why" (p. 13). Ford and Forman go on 
to say that "dialogic speech makes the creation of a third space possible" (p. 9). The 'third space' - a concept introduced by Gutierrez and Rymes (1995) - describes how meaning other than what was originally intended is created through the dialogue/negotiation that occurs between activity systems. As we later show, student work has the ability to function dialogically in the so-called third space, as a boundary object.

Star and Greiesmer (1989) introduced the notion of boundary objects based on an in-depth study of the establishment and ongoing work of a natural history museum. They define boundary objects as the means through which people from different social worlds negotiate meaning despite different perspectives and/or different motives. The actual object may have "different meanings in different social worlds but at the same time have a structure that is common enough to make them recognizable across these worlds" (Akkerman and Bakker, 2011, p. 141). It is through negotiation and sense-making of these objects particular kinds of objects that resonate within diverse social worlds and support dialog about, and progress toward, non-overlapping goals - that learning occurs.

Akkerman and Bakker (2011) link the idea of third space with boundary objects - employing the term 'hybridity' - which they describe as the "production of new cultural forms of dialogue" (p. 135). In their review of the literature on boundary objects, they explicitly ask the question, "What dialogical learning mechanisms take place at the boundaries?" (p. 137). Materially populating these third spaces are artifacts, which take up meaning in cultural practices: how people create and use them. Artifacts of student work both generate meaning through their use and develop meaning along the way - significance that is different to different people. As Miettinen (2006) says, "The objective meaning of money has nothing to do with the material constitution of notes and coins" (p. 399); it is how money is used through cultural understandings that the objects themselves have importance. In our research, for the communitybased experts who have worked with King, what was transformed through their involvement in student work was not their understanding of subject matter (as it was for students) but their notion of children's capabilities. In other words, boundary objects can function to align efforts and communicate value across social worlds without depending on the equivalency of motives or salience

Boundary objects function also as boundary crossings, and create a leading edge for development: "boundaries create a need for dialogue, in which meanings have to be negotiated and from which something new may emerge" (Akkerman and Bakker, 2011, p. 142). How does student work function in this way? And by 'work' we mean not just the products and performances that students create, but the process during which the work is carried out. The answer lies partly in defining what the dilemmas are that are negotiated between local experts and students during their "continuous joint work at the boundary" (Akkerman \& Bakker, 2011, p. 149). From our data, we noticed that students, teachers and local experts work together at the boundary, but via different motives and different dilemmas. For example, when being interviewed by a student about his role in the civil rights movement, an interviewee described the tension for him as whether or not his actions 50 years ago mattered, how students might interpret his actions, and his own emotional response to these students caring about civil rights. Students, at the same time, negotiated the dilemmas of how to act like a historian, how to adequately complete the assignment, and how not to embarrass themselves in front of their peers and the interviewee. The fact that dilemmas were not shared by the individuals did not obstruct joint effort toward producing an object that had value.

Finally, advocates and researchers of project-based curricular designs face the problem of defining value. Even at a school like King, with its extensive history of producing extraordinarily highquality student work, student products (including performances and presentations) are not used or circulated in the way commercially available products or professional presentations would be. In other 
words, things produced by students would, only in rare instances, possess the same degree of use or exchange value as artifacts that are central to professional communities of practice. To appreciate the form of value articulated by participants in our study, and to conceive of the 'zone' that exists when students work with local residents and experts in project-based curricula, we draw on Dewey's $(1925 / 1964)$ materialist theory of aesthetic value, and in particular, his comments on art and experience. We explain Dewey's theory more fully after working with the ideas of boundary objects in our primary research themes.

\section{Methods}

\section{Data Sources}

King Middle School was selected because: 1) It adopted a whole-school reform model called Expeditionary Learning in 1993 and it is considered exemplary within this national network of over 160 schools; 2) King, the most diverse middle school in Maine, serves a socio- economically, culturally, and linguistically diverse student population ${ }^{2}$, providing a context in which to explore school reform from an 'opportunity to learn' perspective (Moss, Pullin, Gee, Haertel, \& Young, 2008); and 3) Students consistently perform higher on standardized tests than other schools serving similar populations while also outpacing state averages, though the main engine for student activity is project-based work.

Our research consisted of ethnographic fieldwork that spanned from January, 2010 until June, 2012. One aspect of this project involved following a three-month-long interdisciplinary $7^{\text {th }}$ grade project on the civil rights movement, called Small Acts of Courage, and traced the use-value of what students produced: 1) Bound books containing written narratives based on in-person interviews with local people who had played a role in the civil rights movement; and 2) A culminating event during which all $807^{\text {th }}$ graders took the stage in front of over a hundred people in a well-rehearsed performance of their learning. This investigation was conducted in the historical context of students creating and sharing high-quality work with audiences across the 25-year history of school reform at King.

Data collection included: 1) interviews with teachers, administrators, students and local experts; 2) supporting material artifacts; 3 ) video and audio recordings of whole-class and small-group work and 4) extensive fieldnotes.

As is most relevant to this paper, the following are short descriptions of each of the five local experts who were interviewed. Interviewees were selected through recommendations by King staff, connections to long-standing projects at the school, and by picking a representative range of project types and roles in the community.

- John - Although knowledgeable about King for many years, it wasn't until John was asked in 2010 to be an interviewee for the Small Acts project that he became more involved in this school. A minister of a socially and politically progressive local church, John had been involved in civil rights since a teenager in the early 1960s.

- Jeff - In the late 1990s, Jeff was first asked to collaborate with teachers from King to design academic projects. As the city arborist, Jeff has been involved in a range of projects with students including creating field guides to local natural areas and inventorying the health of trees planted in public spaces.

- $\quad$ Susie - As the head of special collections at a local university, Susie got involved with King when contacted by a teacher who wanted to bring students in to look at artifacts from the African American special collections.

- $\quad$ Ed - Ed's involvement with King spans multiple perspectives: former mayor of Portland, city councilor, parent of two King students, and public school advocate. He worked with students on several projects, including inviting

\footnotetext{
${ }^{2}$ In the 2010-2011 school year, King's student population was 55\% Free and Reduced Lunch, 51\% minority, 36\% English Language
} Learners, with 25 different languages spoken. 
students to testify at a public hearing about reducing pollution in Casco Bay.

- Fred - A water quality specialist, Fred has worked with teachers and students at King on a longitudinal study of the Presumscott River. Fred was a student at King in the 1980s and was a parent of a student at the time of the interview. He has noticed a dramatic difference in the school he went to as compared to today.

\section{Data Analysis}

We adopted a grounded theory approach to data collection and analysis. The process consisted of: 1) Interpreting data by generating theoretical concepts about the meaning of 'making student work public' at King over time; 2) Coding relevant episodes of interviews, fieldnotes, artifacts and audio/video in part using in-vivo codes that relied on people's actual words (Saldana, 2009); and 3) Using focused coding to build categories and using the constant comparative method during initial rounds of open coding (i.e., comparing data with data and then comparing data to codes). The strategy of collecting multiple types of data was critical; it allowed us to compare within and across types of data (Seaman, 2008). Throughout, we used Clarke's (2005) notion of Situational Analysis to assist in "'opening up' the data and interrogating it in fresh ways" (p. 83).

As shown in the next section, major coding themes, as established through the larger research project, were specifically corroborated and expanded upon given the interviews with local experts.

\section{Analysis/Findings}

In this section, we discuss three themes that emerged from our analysis of the data as they relate to our questions about local experts and student-work-as-boundary-objects: 1) Being peered into; 2) Performing student work; and 3) Getting all students to the top of the mountain. Although other themes emerged from the larger research study, these three intersect with students working with local experts. Here we explain the three themes broadly and their relationship to each other. Each theme is then explored in depth, after which we discuss implications.

Historically, King moved from tracking to heterogeneous grouping, a process that started in the late 1980s. Consciously transforming to a school where all students were given the opportunity to succeed meant adopting a philosophy of "all students getting to the top of the mountain." This entailed dramatic shifts in approaches to curriculum design, teaching practices, and collaboration among staff and students. At the heart of these reform efforts, were projects that had relevance to people outside of the school and the notion of 'making student work public' - sharing results of student learning in front of local audiences. Preparing for and sharing performances of student work created a way that students, teachers, community partners, and the school-as-a-whole where "peered into."

\section{Being Peered Into}

Students 'sharing their work with an audience' created an inherent mechanism for students, teachers, and the school-as-a-whole to be peered into. Putting work up on a stage - having people outside of the school witness students' academic learning - invited scrutiny (usually positive, though potentially negative) across stakeholders. However, by being part of the process of students' work, local partners also were 'peered into' in interesting ways. By sharing their work with students, young people bore witness to the professional lives of the local experts. This mattered to these adults, and each spoke about it in different ways.

John, who was interviewed for the Small Acts project, had an emotional experience while recounting his experiences during his interview with students and at the culminating event. John said that the work that students produced was so important to him that, "I have it in my archive of things to keep 
forever." He also said, "part of the emotion that I felt was that this was exactly what the whole civil rights movement was about and there it is right in front of me;" in other words, that this diverse group of students was learning together and caring about civil rights. He also described what it was like for him to watch students react to his stories, for them to listen to his involvement in the civil rights movement and write about them. He said, "To them, of course, 1965 is ancient history, and to me, I was a pretty young man in ' $65 . .$. but there was almost a jaw drop from the kid who was asking the question. Like, 'oh my gosh, really?'" In detail, John described the historical moment ${ }^{3}$, as he had told it to students, "....but there was also this undergirding sense that history was being made. This was the right thing that and this was the right place and that $I$, in that moment, not only was U.S. history being shaped, but I was being shaped. It was big." John re-contextualized his own memory of this moment, by telling it to students, by having students be in awe of these details. He said,

\footnotetext{
I was feeling it again too. I'm an emotional person and my compassion for that experience and telling it to the kids was just very moving. It's very powerful and of course there's a bond that happens in that when someone's giving their own testimony of anything and those listening can feel the emotion of re-visiting that time and place. It was very special...I would never have thought of myself as a history maker or anything particularly notable. Just '[John] doing what he's able to do.' But recognizing in the kids and the project helped me perhaps to better value what was going on and the fact that I was there.
}

Other local partners described the value of working with students because they could see their own professional interests being passed to a new generation - some of whom may choose their profession as their own. For instance, it was inspiring to think that their passion for environmental protection could potentially live on through students' work, not just in these projects, but following them into high school and beyond.

Additionally, each of the interviewees compared themselves to King students, saying that they could not imagine themselves as middle schoolers producing the quality of work of these students. Working with students gave the local experts the opportunity to examine their own experience as students: King students seemed to care so much more about their work than they ever did.

The kinds of things students and local partners worked on together, created a reciprocal nature of 'being peered into.' Not just students - but also adults in the community - had the chance "to look at oneself through the eyes of other worlds" (Akkerman \& Bakker, 2011, p. 146). As shown in the next theme, the students performing their work was the vehicle through which this 'being peered into' occurred.

\section{Performing Student Work}

The type of work that students did alongside local experts was important - it often stemmed from local needs and questions. Some of this work generated lasting material artifacts - such as the field guide depicted earlier - and some was performed for audiences. Students and local experts performed their work during the process and as an end result.

As stated in the introduction, adults often have an emotional response when watching children share their work. Each interviewee described the tears they shed when watching students perform their work up on a stage or give a speech to the city council. John said he was on the edge of his seat during students' culminating performance of Small Acts. He said he "felt himself leaning into" the students'

\footnotetext{
${ }^{3}$ The 'historical moment' John referred to was marching with Martin Luther King Jr. in Selma, Alabama - specifically crossing the Edmund Pettus Bridge.
} 
performance, willing them along, rooting for their success with his body language, "sending energy their way." Connecting back to notions of aesthetic experiences, Greene (2001, p. 10) echoes this idea saying,
You are going to discover, sometimes with a veritable shock of awareness, the degree to which such understanding enables you to move out toward, to be present at performances and created works, the degree to which knowing can open perceptual possibilities and, indeed, enable us to feel more, to sense more, to be more consciously in the world.

Ed described a scene from King's annual Celebration of Learning, held at the city's Expo Center each spring, at which students displayed and discussed their work from throughout the school year to people outside of the school:

\footnotetext{
... there were 15 or 20 adult educators clustered around this young boy and he just with confidence and poise... I was almost in tears watching that and afterwards talking with him...man, you reached in you grabbed that kid, you challenged him, but you also supported him. And now look at him. That to me is what I would call a trajectory changer.
}

To Ed, it was moving to witness a student transformed through the process of performing his work. Ed believed that this kind of experience positively shaped the direction of some middle school student's lives.

Local experts also described what it was like not just to be an expert - a resource for students but to work alongside students, as John said, "crafting something together." Jeff, spoke at length about the quality of work that students did alongside him during their citywide inventory of the health of publicly planted trees. To have students doing legitimate work - contributing to a real database - with him and not just for him, mattered to Jeff. He was deeply proud of the work they did together.

As previously stated, performances were not just the end result, but constituted the process itself: local experts were asked to assess student work and provide feedback. For example, in Small Acts, the interviewees read through near-final drafts of students' writing. John described the experience saying,

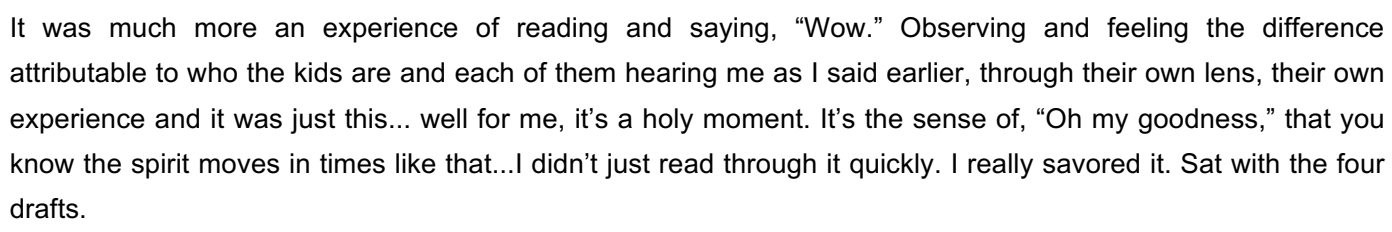

Although difficult to describe the nature of having a "holy moment," it was clear that he had an intense experience working with students' writing, that he took their work seriously, and that their work was deeply moving. Fostering this was a combination of the quality of students' work and that students cared specifically about his story and more broadly about civil rights.

Each of the interviewees discussed how they were impressed by the quality of students' work and students' level of preparedness for all types of performances. It was clear to them how hard students worked; they all remarked on students' poise and professionalism. When asked about the quality of students' work John said:

It's stunning. It's really both the format and then the actual narrative that the kids created...that's a remarkable piece of work. And to have it...presented in this way gives the kids that additional sense of 'this is very special, 
it really matters.'... it's not just ... quickly produced like the things that you and I had when we were in school. This is a keepsake and it's really a very beautiful rendering of the stories and I think for the kids to have the experience not only of doing ... every step of the project, but seeing this as the outcome and having a sense that they, the students, the teachers were in this project together and that it created something of lasting value and lasting significance is just huge. I mean it's remarkable. I admire and affirm that so much that they were able to create something like this.

As stated here, that students produced lasting artifacts of their work - bound books, websites, videos mattered. These material objects acted as ongoing mediators of local partners' understanding of the work, as well as created the possibility for others to understand.

With little prompting, interviewees excitedly showed us what kids had produced. One person hurried to every corner of his office grabbing pieces of students' work. The interviewees were proud of these artifacts. During the interview, artifacts of student work became mediators between us-asresearchers and the interviewee. Through local experts describing and showing the features/qualities of students' work, they recounted the process they went through, the use of that product afterwards, and their beliefs about the value of student work.

In a notable exception, when asked about the quality of student work, one person said that she had not read what students had written. Although she expected the quality of the writing to be high, she thought "it was a symbolic gesture" that the students' work was placed in her archive. She did think that students' work would be used in the future; however, she saw the value more "as an example of an educational process." (See the next section for more examples of how student work was a means for adults understanding the possibilities of schooling).

As described in the above examples, students' artifacts and performances served different needs and fulfilled different roles, depending on one's frame of reference. From the local experts' perspective, the products and performances sometimes served an instrumental role, having direct use value as intended. The city arborist said that what students produced in one project (in the form of a short video) was better promotion for his office and his work than anything he or other adults possibly could have generated. Ed, former mayor, described how students were by far the best advocates for an initiative he tried to get support for from city council. He said:

One of the reasons why the King students were so effective - in addition to their knowledge, content, and presentation skills - was in fact their very presence was a very visible statement that this really wasn't so much about us, about people my age (as I call it 'the old farts') this is about the future and that it is the young people in Portland who will be the greatest beneficiaries of the investment we make now.

He also said:

It was out of rational self-interest on my part as mayor at the time that I asked the students, "Would any of you be willing to volunteer to come to the city council?" And my primary motivation was, I needed their help. So, I think that is testament to the quality of their work and the quality of their presentation skills and that when they came, as I said, they were the most effective advocates. More so than the folks from the state department of environmental protection of the other environmental advocacy groups.

In this case, it was only partly what students created or produced that had value; to Ed, it was also the students themselves that had use value to his mayoral initiative. 
As conveyed more specifically in the next theme, part of the impact of students' performances on local experts was that all students participated, together, and with high quality. One interviewee said that witnessing King students' performances helped him have 'elevated aspirations' not just for schooling, but for the entire city of Portland. He said, "I mean, you couldn't sit through the culminating events... and not, in my opinion, have elevated aspirations for how our community should be able to relate to one another."

\section{Getting All Students to the Top of the Mountain}

When the principal (who stayed on until 2016) took over in 1988, King Middle School was a tracked school, with seven levels of students grouped according to purported ability. In an effort to detrack King and to create a school with heterogeneous grouping, the principal was inspired by an Outward Bound metaphor: instead of getting a few students to reach academic heights, the school instead would help all students reach the top of the mountain. The metaphor of "getting all students to the top of the mountain" pervaded teaching and learning at King and was resoundingly heard in the words of the local experts. Here we explore two sub-themes: 1) How working with students shaped community experts' notions of what diverse groups of students were capable of; and 2) How this work also shaped their understanding of the possibilities of schooling.

Interviewees spoke about their newfound knowledge of what it took to pull off a school like King. Several worked with other schools, and they said there was a notable difference. This partly related to how hard teachers at King worked, but it was also about teachers' ability to collaborate with people inside and outside the school - that instead of simply seeing the expert as a guest/invited speaker, they saw them as a partner. For example, Ed saw teachers as leaders alongside the school's principal, saying that, "The power of collaborative leadership is evident at King."

The quality of students' products and performances shifted each person's understanding of not just what any one student was capable of, but the possible accomplishments of racially, linguistically, and socio-economically diverse groups of students. One person said, "a strong mix of all sorts of students that it wasn't just the kids who were from affluent families that excelled." He went on to say,

\footnotetext{
...my own bias that when I first met the students - I met them all [90] at once and so it was really my first impression...kids from all walks of life, different socio-economic backgrounds and I was really impressed that they all achieved at the same level and when I got the final product I couldn't pick out any of the individuals... because they all excelled and I think that part really surprised me the most.
}

In describing King, one interviewee said, "I reduce it actually to one very short phrase, which is what King does really well, is they challenge every single student." He said each of these last three words slowly and deliberately, hitting the table with his hand for emphasis...every (bam!) - single (bam!) - student (bam!).

Seeing 'all students get to the top of the mountain' led several people to become champions of public school reform. As Ed said, "One of the downsides of being a King parent, and I mean this seriously, is it makes you a lot less tolerant of the mediocrity elsewhere in the school system." Ed was very vocal in his view of public schooling, saying that since he has seen the possibility of excellent schooling, "less than King" was intolerable.

Related to the previous 'elevated aspirations' quote, seeing all students 'get to the top of the mountain' prompted one person to say, "This is the way we want Portland to be." Students at King, performing their work publically, showed people outside the school that diversity was an asset and gave people "a glimpse of what Portland can be." 


\section{Discussion}

\section{The importance of aesthetics}

It could be argued - as Star and Griesemer (1989) did - that the effectiveness of boundary objects lies in their ability to facilitate alignment of use values. Examples in our data support this, as when Ed invited students to make a presentation because it would more effectively sway opinion than hiring paid professionals. In our view, however, student work cannot be understood only in this way, given the disparities of value across stakeholders' social worlds and the often sentimental - even spiritual language interviewees used when speaking about student projects and performances. For projects to achieve maximum motivational potential - or so the arguments go - students must perceive that their products have utility for some other audience. Often this means a community organization or interest. However, actual utility is only rarely true, and becomes increasingly unlikely earlier down in the K-12 range. Even if students do occasionally produce something that approaches professional work, this does not hold systematically across all instances of student projects. The rarity of students (a) working on something efficiently, and (b) producing something truly of professional quality would not be sufficient to sustain the claims or the enthusiasm of project advocates. Finally, teachers and administrators are likely both unqualified to determine use-value at a professional caliber (say, judging architectural plans) and unmotivated to do so: their qualifications lie in promoting and assessing learning. The 'use-value' of student work for them lies therefore in its ability to demonstrate that learning occurred. Despite these discontinuities, project work continues to captivate and satisfy all parties. So how might analysts fruitfully understand value?

First, it is helpful to consider student products and performances as mediating artifacts that dialogically enable boundary crossing. Mediating artifacts are central to sociocultural perspectives on human growth and development. Not all artifacts promote boundary crossings and so it is important to consider what qualities contribute to negotiation/new understandings across diverse perspectives. And, in our case, when examining students' products and performance, how can we understand the 'quality' of these creations, how local experts interact with them, and why this work seems so important to children, teachers, and people outside of the school? A possible answer lies in the aesthetic domain.

Several scholars have made connections between what is broadly thought of as sociocultural perspectives on learning - CHAT in particular - and the work of John Dewey. Notably, Miettinen (2001) makes connections between Dewey and CHAT that revolve around a materialist epistemology, focusing on the use of tools. Mietinnen represents Dewey as believing that, "The world is known only in purposeful transformation of objects" (2001, p. 302). Dewey is known as an instrumentalist, giving material items and labor a central role in in expanding human culture and capability. But he was also supremely concerned with aesthetic value. In what follows, we turn to the periodic instances where Dewey's materialism and aesthetic sensibility intersect with his educational prescriptions.

Dewey's notion of a "genuinely aesthetic object" serves as a starting place to make sense of student work as boundary objects, what occurs at the boundary between the social worlds of students/teachers/school and out-of-school experts. In his later works, Dewey (1925/1964, p. 161) discussed aesthetic objects as being both instrumental and consummatory. He wrote,

\footnotetext{
... a sure demonstration that a genuinely aesthetic object is not exclusively consummatory, but is causally productive as well. A consummatory object that is not also instrumental turns in time to the dust and ashes of boredom. The 'eternal' quality of great art is its renewed instrumentality for further consummatory experiences.
} 
Dewey further argues that true art is not an item of beauty that only a few elite specialists enjoy, but rather is "a union of the serviceable and the immediately enjoyable, of the instrumental and the consummatory" (p. 161). By 'consummatory' Dewey meant the inherent qualities of art taken in by a person; by 'instrumental' he meant the role the work played in experiential conditions (Westbrook, 1993). He desires 'art' that embodies both qualities, allowing the object to endure over time and propel future experiences; it does not turn into 'the dust and ashes of boredom.'

Additionally, Dewey argued that art was more than a static object hanging on a wall, but it was through a person's experience with that artifact that the significance came alive, largely through the cultural notions that shaped that experience. Along these lines, Dewey argued that art should not be separated from everyday life but rather infused as a sensibility in experience (Westbrook, 1993). Westbrook says about Dewey, "At the heart of Dewey's aesthetics...to trace the continuities between the work of art and the doings and undergoings of everyday life" (p. 390). For Dewey, aesthetic experience was its highest form, uniting instrumental and consummatory values, and enlarging subjects' emotional and intellectual capacities for appreciating and reconstructing culture. As Wong (2007) writes, citing Rosenblatt (1978), "In the end, we construct efferent meaning to be 'carried away' from the immediate, aesthetic situation. The experience becomes 'meaningful' as the aesthetic and efferent are inextricably related to one another. The value of an educative experience is the enrichment in our lives both in that moment and in subsequent experiences" (p. 207).

What student produce through their school work can be instrumental - it can serve a specific purpose - whether in exchange for a grade (Lave, 1991) or reducing the amount of solid waste generated by students' school. It can, in other words, have exchange value or it can have use value. In actuality, student projects are likely often constituted by varying degrees of both. Student work can also be consummatory. For example, when students create and perform a play in front of a live audience, the audience is emotionally and intellectually rapt. But, when student work contains both instrumental and consummatory qualities, it is both serviceable and beautiful - artful, in the Deweyan sense. It is this work that climbs out of the 'economy of the wastebasket' and has the potential to serve as boundary objects. Seeing student work in this way also allows us to reconcile the discontinuity of value that constitutes most project-based work, providing an explanation of how and why it sustains and satisfies so many diverse stakeholders. Moreover, it helps to derive criteria for evaluation that places some stringent requirements on the kinds of work that schools have students do. From this vantage point, most of what students do including seemingly unending standardized tests - falls far short of having worthy value.

One teacher described Small Acts of Courage as the 'never ending expedition,' because what students created had a life of its own, in unpredictable ways, after the purported 'end' of the project. Artifacts of student work were passed among community members; sat on the shelves of the local university's special collections library; were shared as PDFs on the school's website. That students created this work was not enough for these objects to continue to 'act' or promote dialogue; it was the aesthetic quality of student work, the ways in which students conducted themselves during their interviews and at their public performance of their work that caught the attention of audience members. These beautiful moments propelled their work into enduring, active, meaning-making, dialogic roles.

\section{Implications for the dialogic potential of student work}

As discussed throughout this paper, there are specific features of the work that students produce at King that foster boundary crossings, including: 1) the aesthetic quality of the products and performances that students create alongside local partners; 2) that students produce artifacts that have and create social meaning; and 3) that King has a history of this type of work that has endured over 20 years. 
In our case, why exactly does aesthetics matter? Why work with children to create products and performances of academic work that are both instrumental and consummatory, that have use value and continue to give pleasure after the consummatory event - indeed, whose meanings continue to evolve? Why connect children and local experts through this kind of work, or more provocatively, use it as criteria for curriculum design and assessment? Greene (2001), in discussing Dewey's notion of aesthetic education says, "That meant removing arts from their pedestals and equipping all kinds of people to engage with them, to lend them their lives. And it meant enlarging the domain of the arts so that all kinds of silenced voices could be heard..." (p. 107). As shown in our analytical themes, part of how local experts described the value of their work with students was in witnessing students finding their voice that students who typically might not have the opportunity to shine, were standing up in front of the world and proudly displaying their work.

In this paper we have discussed the dialogic possibility of student work as framed by the notion of boundary objects. The quality of student work shaped our interviewees interpretation of what diverse groups of students were capable of. That they had 'elevated aspirations' for individual students (and for schooling in general) is critical; however, that they also transferred this idea to 'the way Portland should be' is demonstrative of boundary objects not just negotiating meaning between social worlds, but actually being the leading edge of development. These descriptions suggest a certain type of dialogue, one in which children not only claim a personal voice through their work but contribute to shared worlds that are imbued with social meaning.

\section{Conclusion - "Planting Trees in Public Spaces"}

Although speaking about the actual value of students' work as "planting trees in public spaces," this comment from the city arborist serves as an apt metaphor for the life span of students' products and performances. First, student work is quite literally rooted in the local community - it exists because it has emerged from expressed needs of people outside of the school and it is presented in public spaces (i.e., the public library's art gallery, in front of city council, books donated to the special collections library). Second, student work lives beyond the completion of the actual product or final performance: it exists in the public sphere, shaping local partners' notions of what it means to do school, of the power of students finding their voices.

For student work to be considered dialogic is a radical departure from how typical student work functions. Evidence of academic achievement that is reduced to test scores (as is increasingly present in the current climate of standards and accountability) truncates the possibility of school-community partnerships. Rather than leveraging school-community partnerships in service of improved test scores, we argue for work that is mutually beneficial, that opens up possibilities for new understandings and possible trajectory changers for both students and local partners.

\section{References}

Akkerman, S. F., \& Bakker, A. (2011). Boundary crossing and boundary objects. Review of Educational Research, 81(2), 132-169.

Apple, M. (1990). Ideology and curriculum. New York, NY: Routledge.

Baker, P. H., \& Murray, M. M. (2011). Building community parterships: Learning to serve while learning to teach. The School Community Journal, 21(1), 113-127. 
Blumenfeld, P. C., Soloway, E., Marx, R. W., Krajcik, J. S., Guzdial, M., \& Palincsar, A. (1991). Motivating Project-Based Learning: Sustaining the Doing, Supporting the Learning. Educational Psychologist, 26(3/4), 369.

Clarke, A. E. (2005). Situational analysis. Thousand Oaks: Sage Publications.

Dewey, J. (1925/1964). Experience, nature, and art. In R. Archambault (Ed.), John Dewey on education (pp. 157-165). New York: The Modern Library.

Dewey, J. (1927/1954). The pubic \& its problems. Athens, OH: Swallow Press-Ohio University Press.

Dobbertin, C. B. (2010). What kids learn from experts. Educational Leadership, 68(1), 64-67.

Engeström, Y. (1987). Learning by expanding: An activity-theoretical approach to developmental research. Helsinki: Orienta-Konsultit Oy.

Ford, M. J., \& Forman, E. A. (2006). Redefining disciplinary learning in classroom contexts. Review of Research in Education, 30, 1-32.

Greene, M. (2001). Variations on a Blue Guitar: The Lincoln Center Institute Lectures on Aesthetic Education. New York: Teachers College Press.

Gutierrez, K. D., \& Rymes, B. (1995). Script, counterscript, and underlife in the classroom: James Brown versus Brown v. Board of Education. Harvard Educational Review, 65(3), 445-471.

Lave, J. (1990). The culture of acquisition and the practice of understanding. In J. W. Stigler, R. A. Shweder \& G. Herdt (Eds.), Essays on comparative human development. Cambridge: Cambridge University Press.

Lave, J., \& McDermott, R. (2002). Estranged (labor) learning. Outlines, 1, 19-48.

Magnifico, A. M. (2010). Writing for whom? Cognition, motivation, and a writer's audience. Educational Psychologist, 45(3), 167-184.

Miettinen, R. (2001). Artifact mediation in Dewey and in Cultural-Historical Activity Theory. Mind, Culture \& Activity, 8(4), 297-308.

Miettinen, R. (2006). Epistemology of transformative material activity: John Dewey's pragmatism and cultural-historical activity theory. Journal for the Theory of Social Behavior, 36(4), 389-408.

Moss, P., Pullin, D., Gee, J. P., Haertel, E. H., \& Young, L. J. (Eds.). (2008). Assessment, Equity, and Opportunity to Learn. Cambridge: Cambridge University Press.

Poortvliet, P. M., \& Darnon, C. (2010). Toward a more social understanding of achievement goals: The interpersonal effects of mastery and performance goals. Current Directions i Psychological Science, 19(5), 324-328.

Roth, W.-M., \& Lee, Y.-J. (2007). "Vygotsky's neglected legacy": Cultural-historical activity theory. Review of Educational Research, 77(2), 186-232.

Saldana, J. (2009). The coding manual for qualitative researchers. Los Angeles: Sage.

Sanders, M. G. (2006). Building school-community partnerships: Collaboration for student success. Thousand Oaks, CA: Corwin Press.

Seaman, J. (2008). Adopting a grounded theory approach to cultural-historical research: Conflicting methodologies or complementary methods? International Journal of Qualitative Methods, 7(1).

Sidorkin, A. M. (2001). Labor of learning. Faculty Publications, Paper 16. 
Star, S. L., \& Griesemer, J. R. (1989). Institutional ecology, 'translations' and boundary objects: Amateurs and professionals in Berkeley's Museum of Vertebrate Zoology, 1907-39. Social Studies of Science, 19, 387-420.

Wardekker, W., Boersma, A., Ten Dame, G., \& Volman, M. (2011). Motivation for school learning: Enhancing the meaningfulness of learning in communities of learners. In M. Hedegaard, A. Edwards \& M. Fleer (Eds.), Motives in children's development: Cultural-historical approaches (pp. 153-169). Cambridge, U.K.: Cambridge University Press.

Westbrook, R. (1993). John Dewey and American Democracy. Ithaca: Cornell University Press.

Wong, D. (2007). Beyond control and rationality: Dewey, aesthetics, motivation, and educative experiences. Teachers College Record, 109(1), 192-220.

\section{(cc) EY}

New articles in this journal are licensed under a Creative Commons Attribution 4.0 United States License.

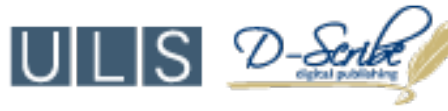

This journal is published by the University Library System, University of Pittsburgh as part of its D-Scribe Digital Publishing Program and is cosponsored by the University of Pittsburgh Press. 